\title{
To explore the clinic education reform of "legal profession qualification
}

\section{examination"}

\author{
Hou Shuo ${ }^{1}$ \\ ${ }^{1}$ School of Humanities and Social Science, North China Electric Power University, Beijing 102206, \\ China
}

Key words: legal clinics; clinic education; legal talent; legal professional qualification examination.

\begin{abstract}
: the clinic legal education is the most important two goals, is to improve the students' legal practice level and strengthening professional ethics accomplishment, to supplement and improve the traditional teaching mode of the law.The eighteen of the communist party of China passed by the fourth plenary session of the "about promoting the rule of law certain major issue decision", put forward to the implementation of "unified judicial examination" change to "legal profession qualification examination.Clinic legal education on students' demands and to the legal profession talented person is consistent, clinic legal education for is going to take the exam of the students has an important function and meaning.
\end{abstract}

\section{Introduction}

In the $1990 \mathrm{~s}$, the clinic legal education was introduced from the United States some domestic colleges and universities.At the time, shall be deemed to promote and perfect the effective exploration of legal education reform in China.From all colleges and universities to carry out the national law education of clinic type more than ten years, the legal profession talented person's raise law in our country, especially the cultivation of the legal professional ability and professional ethics, played an indelible role.At present our country is brewing a new round of reform of the judicial examination - would began in 2001, the implementation of the 15 years of "unified national judicial examination reform" to "unified national legal profession qualification examination".Predictably, this reform will be profound - not only the reform of the examination content and form, but also for China at present, the entire law teaching and the reform of legal education, legal clinics in education exploration and advocating the direction of change.

\section{The Current Our Country the Main Problems Existing in the "Unified Judicial Examination" :}

According to incomplete statistics, since 2002, has more than 40, ten thousand people through the "unified national judicial examination", not only makes our lawyers, judges, prosecutors and greatly enrich notaries team, also obviously improve the professional quality of legal talent, to some extent, improved the legal professionals in the early 21 century social background, cultural level, business level is uneven.For law education and judicial examination, the influence is also significant: domestic most of the college of law (or law) according to the requirements of judicial examination and the spirit, for the content of courses, teaching methods and examination to change, to adapt to the "unified judicial examination" mode of social demand for outstanding legal talent.

Grades are verygreat, but there is no denying the fact that judicial examination is increasingly 
exposed some problems.Especially in recent years, as the country of the rule of law and legal professional talent training is becoming more and more attention, "unified judicial examination" to ridicule, and considered it reflects the many problems that exist in the law education in our country at present.

Duality of legal science educators universal law education at home and abroad academic and practical.On the one hand, a strong legal education theoretical and academic atmosphere, just for undergraduate phase, often a common core of law course teaching material is at least more than 400 pages.It pays attention to cultivate the students' theoretical accomplishment, academic features prominent;Legal education, on the other hand, practical characteristics also clear.Its essence is a kind of vocational education, students graduate from law school eventually belong to society, is to work in the legal services.University education stage of law, therefore, need to cultivate the students' career in the legal profession skills through practice and ability, this is also the most important mission.[1]

Legal education the duality of this should be a mutual promotion, the organic combination.But unfortunately, due to long a copy of the former Soviet union law education, legal education in our country, the dominant teaching and instill legal theory knowledge, and ignore the law practice education for a long time, causing legal professional personnel training problems.Problems reflected in the judicial examination, main show is attaches great importance to the law of memory and ignore the practicality of the examine.Specific performance has the following three aspects:

The heavy light use of knowledge, memory ability.The current judicial examination to test the content of each year, are in a preset area (the so-called "exam outline" and the "big three" teaching material), draw after the examination by the justice department also released unified standard answer.Take part in the judicial examination of the candidates, just according to the traditional learning mode, basic theoretical knowledge and the relevant law laws and legislation to enhance memory, mechanical memory, to be able to understand and remember law is all bad.This way of examination, can only make the student to obtain static, fixed knowledge on book, one of the biggest drawbacks is the vast majority of references at the end of the exam examine, would the test through mechanical memory to remember the legal knowledge of all forgotten completely.

The examination of formal law practice.Although the judicial examination of the current our country is not completely examines the examine to legal practice ability, but the test form is greater than the essence, is completely through the way of examination question.Even in recent years, in the fourth volume of judicial examination examination questions, proposition people consciously stepped up some objective questions there is no standard answer, especially in proportion to the case analysis problem, but the approach overall or become a mere formality - although the examination subject design a considerable proportion of case analysis, and these subjects have overall comprehensive, system, focusing on features, but the question is compared commonly simple, the answer can be found directly on the law mostly, don't need to use a law practice ability.[1] So the case analysis problem is more like to stack a number of multiple choice, so just want to this way to screening qualified, have enough practical application ability of legal talent will undoubtedly bring a lot of problems.Even through judicial examination, candidates with the actual legal practice ability, and far cannot reach legal professional talent training required levels of ability.

From the legal profession talented person demand.Law education in 21st century China is shouldering the important task and arduous historical mission and reality: not only to cultivate a group of outstanding talents of law and a number of highly qualified and implemented to promote the rule of law in China great dream at the same time, cultivate a large number of social and economic development in governance, management, the task of governing talents.[1]Therefore, the 
social from all walks of life generally have high hopes for judicial examination, hope through judicial examination can do the selection to the moral, intellectual, physical, all-round development of the legal talents, the work of political science and law.But from the current judicial examination in a large extent the diversification of Chinese society of legal professional talent demand, especially ignored the basic rule of law of the community work need a lot of, in legal talent "pyramid" basic parts of a large number of legal professional talent selection.Therefore, judicial examination examination must conform to the social needs, social needs of talent cultivation.

\section{The Law Clinic Type Teaching the Basic Connotation}

Aiming at the problems existing in the uniform judicial examination, the more the reflected by the judicial examination to our country law problems existing in the professional personnel training, the author thinks that originated in the laws of the United States the clinic teaching model for solving a series of problems has an important significance, there are two reasons for this:

Legal clinic teaching really did take the student as the main body in the educational legal clinics, the instructor is "director", the student is a "lawyer".It is not empty.Clinic after the "business", "open case" need "lawyer", personally contact life vivid cases, compared to the textbook, judicial examination papers on the case, the real is much more complicated cases, students must to found the problem, analyzing problem, which could solve the problem.Case, once the students meet with difficulties, not only for teacher's help, should take the initiative to find the law, more explanations, apply law rules, finally to fix the problem.Clinics in legal education mode, the clinic's students to deal with a real case, not only to master the basic knowledge of legal theory, especially the legal procedure of civil litigation, criminal litigation, should put the books on the abstract knowledge into more specific solutions, change passive to active application of memory, memorization for practical use.Really do take the student as the center.

Legal clinic teaching style to deal with real cases as the education contentLawteaching clinic with a special focus on the real case is dealt with, especially pay attention to the social vulnerable groups, such as migrant workers and left-behind children, spouses, etc. To provide legal aid, not only can exercise the student's legal skills, more important is to carry forward spirit of socialist rule of law.This handle is different from the case of actual case teaching and the moot court, also different from the arrangement of legal science specialized students in colleges and universities for all kinds of trainee and practice.It is based on real material based on the background of parties and real cases.Students trying to deal with real cases, is the real, mainly involves: the receiving party, mediation, participate in negotiations, legal relation and the lawsuit accusing the work, such as writing legal documents, some senior, high level of clinic students can even appear in court to citizenship to participate in the litigation.This is similar to the British Barrister and Solicitor system, through to deal with real cases, although the vast majority of limited to accusing the case.Still can let clinic students use their mastery of the legal theory knowledge in a timely manner, to practice, to promote learning.

\section{Legal Clinic Teaching Mode for The Meaning of "The Legal Profession Qualification Examination" in Our Country:}

The clinic law teaching is helpful to cultivate the students' practical ability. As has been pointed out that the current judicial examination of legal practice abilities become a mere formality, and brewing, after the reform of the "unified national legal profession qualification examination" will adopt more flexible and reasonable way to strengthen the examination of legal practice ability.Legal 
clinics and mentioned the teaching, pay attention to "with case", there is no ready-made answer already, also does not have the s doctrine, students need to specific case analysis, and judgment, and creatively to solve the problem.In handling cases, learn to scheduling knowledge in my own mind, to weigh the various factors such as law, ethics and human feelings.Law clinic teaching than just rely on the textbook knowledge can cultivate the students to find more law, analysis law, explains the law and the ability to apply the law, can calmly deal with professional qualification examination of the objectivity and practical subject.

The clinic law teaching is helpful to cultivate the students' professionalethics. Have a qualified legal professionals, really need what kind of work ethic?Each person's answer may not be the same.But the pursuit of fairness, impartiality and justice as the embodiment of the legal value, must be included in the legal professional ethics should be.China's current "legal ethics" is the concept of a virtual, reflected in judicial examination level, is characterized by examination way of "legal ethics" - mainly depend on the number of papers a choice.We can not help but ask: this way to test and the formation of the legal profession qualification have much significance?As you can imagine, after the reform of examination are bound to change the current this kind of method.

Legal clinics in teaching, clinic practice discipline and organization discipline, students must be the same as a practicing lawyer, in each case, his agent is not only to maintain the lawful rights and interests of the parties, seek to maximize the interests of the parties, should stick to principles, to the bottom line, more loyal to their duties, to maintain the authority and the dignity of the national legal system.We can call them "the legal profession of responsibility education", compared with the "legal ethics", this concept is more clear and more practical, its connotation should include how to confidential, how to deal with the relationship between the parties, how to maintain professional enthusiasm, how to coordinate interests with other issues such as the parties.

Legal clinics, in short, teaching is not only to cultivate the legal profession talented person has important practical significance and positive role for brewing in the "unified national legal profession qualification examination" has important guiding significance and more active role, for the future to take an examination of the examine has an important demonstration effect.Therefore, we should actively promote the clinic legal education realize localization, legal education play a clinic in the important role of law education in China.

\section{References:}

[1] Fang Yiquan, ShenXiaoLi. Yi Zhaodi. Law clinic teaching and professional talent training [J]. China's higher education research, 2010 (05)

[2]Li Honghai. Uniform judicial examination and the training and selection of qualified legal talents [J]. Journal of political science and law, BBS, 2012 (04)

[3] Yang Jihui. The application of legal clinic teaching in non-litigation [J]. Journal of liaoning province public security judicial management cadre institute, 2009 (01). 